Vol.45, n. 4 : pp. 413-418, December 2002

ISSN 1516-8913 Printed in Brazil

\title{
Production and Properties of Xylanase from Thermophilic Bacillus sp.
}

\author{
Carlos Alberto Martins Cordeiro, Meire Lelis Leal Martins", Angélica Bárbara Luciano and Roberta Freitas \\ da Silva
}

Universidade Estadual do Norte Fluminense; CCTA/LTA; Av. Alberto Lamego, 2000; 28015-620; Horto; Campos dos Goytacazes - RJ - Brazil

\begin{abstract}
An aerobic, thermophilic, xylanolytic bacterium was isolated from local soil. The results of $16 S$ rRNA sequence comparisons indicated that the isolate was closely related to Bacillus caldoxylolyticus and Bacillus sp strain AK1. These organisms exhibited $94 \%$ levels of ribossomal DNA sequence homology. Studies on the xylanase characterisation from liquid cultures grown on beechwood xylan revealed that the enzyme retained $100 \%$ of activity for 2 hours at temperatures ranging from 30 to $50^{\circ} \mathrm{C}$, while at 60,70 and $100^{\circ} \mathrm{C}, 10 \%, 11 \%$ and $29 \%$ of the original activities were lost, respectively. The optimum $\mathrm{pH}$ of the enzyme was found to be between 6.5 and 7.0. After incubation of crude enzyme solution for 24 hours at $25^{\circ} \mathrm{C}$ and at pH 5.5 to 8.0, a decrease of about $12 \%$ of its original activity was observed.
\end{abstract}

Key-words: Xylanase, thermophilic bacterium, Bacillus sp.

\section{INTRODUCTION}

Biodegradation of xylan, a major component of plant cell walls, requires action of several enzymes, among which xylanases play a key role (Blanco et al., 1999). A wide variety of microorganisms are known to produce xylanases, that are involved in the hydrolysis of xylan (Dimitrov et al., 1997; Sunna and Antranikian, 1997; Sunna et al., 1997; Pham et al., 1998; Beg et al., 2000). Recently the interest in xylanases has markedly increased due to the potential applications in pulping and bleaching processes using cellulase free preparations, in the food and feed industry, textile processes, the enzymatic saccharification of lignocellulosic materials and waste treatment (Van der Broeck et al., 1990; Gilbert et al., 1992; Godfrey and West, 1996; Mechaly et al., 1997; Wong et al., 1988). Most of these processes are carried out at high temperatures, so that thermostable enzymes would give an advantage (Sonnleitner and Fiechter, 1983). Therefore, thermophilic organisms are of special interest as a source of novel thermostable enzymes (Becker et al., 1997; Lee et al., 1999; Beg et al., 2000; Touzel et al., 2000). In the present study, the production of an thermostable xylanase by a Bacillus sp isolated from soil and properties of the crude enzyme are reported.

\footnotetext{
* Author for correspondence
} 


\section{MATERIALS AND METHODS}

Culture medium. Agar plate A consisted of 2\% Bacto-tryptone, $1 \%$ Bacto-yeast extract, $1 \% \mathrm{NaCl}$ and $2 \%$ agar at $\mathrm{pH} 7.0$. This was used for selection of thermophilic bacteria. Agar plate B contained $1 \%$ xylan, $0.2 \%$ yeast extract, $0.5 \%$ peptone, $0.05 \% \mathrm{MgSO}_{4}, 0.05 \% \mathrm{NaCl}, 0.015 \% \mathrm{CaCl}_{2}$ and $2 \%$ agar at $\mathrm{pH} \mathrm{7,0.} \mathrm{This} \mathrm{was} \mathrm{used} \mathrm{for} \mathrm{screening}$ xylanase-producing bacteria.

Isolation and screening. Soil suspensions in sterilised water were poured and spread onto agar plates A. These plates were incubated at $65{ }^{\circ} \mathrm{C}$ for 2 days. The colonies that were found on the plates were transferred onto agar plates $\mathrm{B}$, which were again incubated at $65^{\circ}$ for 2 days. Several xylanase-producing bacterial colonies were selected after flooding the plates with $0,1 \%$ aqueous Congo red for $15 \mathrm{~min}$ followed by repeated washing with $1 \mathrm{~mol} \mathrm{~L}^{-1} \mathrm{NaCl}$ (Gessesse and Gashe, 1997). All colonies showing a clear zone on agar plates were further screened by growing them in liquid medium and assaying enzyme activity from the cell-free culture supernatant fluid One strain, designated as Bacillus sp was selected for further experiments.

16S rRNA sequence analysis: The genomic DNA was extracted from the isolate and the amplification of the 16S rDNA was performed through PCR technique. The purified PCR products was sequenced on an automated DNA sequencer (ALFexpress, Pharmacia). The 16S rDNA sequence of isolate was aligned with the $16 \mathrm{~S}$ rRNA gene sequences of various members of the genus Bacillus obtained from the Ribosomal RNA Database Project and from Genbank (Larsen et al., 1993). Matrices of evolutionary distances were computed from the sequences alignments by calculating a pair wise Jukes-Cantor (Jukes and Cantor, 1969). From these distances, phylogenetic trees were inferred by a neighbour-joining method (Saitou and Nei, 1987).

Enzyme production: The growth medium used for xylanase production contained $(\mathrm{g} / \mathrm{L})$ : beech wood xylan 10.0, yeast extract 2.0, peptone 5.0, $\mathrm{MgSO}_{4} 0.5, \mathrm{NaCl} 0.5, \mathrm{CaCl}_{2}$ 0.15. The $\mathrm{pH}$ was adjusted to 7.5 and the medium was sterilised by autoclaving at $121{ }^{\circ} \mathrm{C}(15 \mathrm{psi})$ for $15 \mathrm{~min}$. This medium ( $50 \mathrm{~mL}$ in $250 \mathrm{~mL}$ erlenmeyer flasks) was inoculated with $1 \mathrm{~mL}$ of an overnight culture and incubated at $50{ }^{\circ} \mathrm{C}$ with vigorous aeration in a shaker at $150 \mathrm{rpm}$ for 144 hours. Before assay, the cells were separated by centrifugation at $4500 \mathrm{~g}$. The clear supernatant was used as crude enzyme preparation.

Enzyme assay: Xylanase activity was assayed by measuring the release of reducing sugar from beechwood xylan following the dinitrosalicylic acid (DNS) method (Miller 1959). To $1.8 \mathrm{~mL}$ of substrate in phosphate buffer, $\mathrm{pH} 6.5,0.4 \mathrm{~mL}$ of culture supernatant was added and incubated at $90^{\circ}$ C. After $10 \mathrm{~min}, 2.0 \mathrm{~mL}$ of DNS solution was added to the reaction mixture and boiled for 10 min. Absorbance was measured at $540 \mathrm{~nm}$ against a reagent blank. One unit of xylanase activity was defined as the amount of enzyme that released 1 $\mu \mathrm{mol}$ reducing sugar equivalent to xylose per min under the above assay conditions.

Effect of pH on activity and stability of xylanase: Effect of $\mathrm{pH}$ on the activity of xylanases was measured by incubating $0.4 \mathrm{~mL}$ of enzyme and $1.8 \mathrm{~mL}$ of buffers, adjusted to $\mathrm{pH}$ of 5.5 to 8.5 , containing beechwood xylan $(0.5 \%)$. The buffers used were:sodium acetate buffer, $\mathrm{pH}$ 5.5; phosphate buffer, pH $6.0-8.0$; Tris-HCl buffer, $\mathrm{pH}$ 8.5. Stability of the enzyme at different $\mathrm{pH}$ values was also studied by incubating the enzyme at various $\mathrm{pH}$ values ranging from $5.5-8.5$ for 24 hours at $25^{\circ} \mathrm{C}$ and then estimating the residual activity.

Effect of temperature on activity and stability of xylanase: The effect of temperature on the enzyme activity was determined by performing the standard assay procedure as mentionated earlier for $10 \mathrm{~min}$ at $\mathrm{pH} 6.5$ within a temperature range of $40-100^{\circ} \mathrm{C}$. Thermostability was determined by incubation of crude enzyme at temperatures ranging from $40-100^{\circ} \mathrm{C}$ for 2 hours. After treatment the residual enzyme activities were assayed.

\section{RESULTS AND DISCUSSION}

Identification of organism: The strain isolated was categorized as thermophilic since it required a temperature range to grow of $44-70^{\circ} \mathrm{C}$. It was unable to grow outside this range.

An analysis of the 16S rRNA gene of isolate revealed that this organism was closely related 
phylogenetically to members of the genus Bacillus rRNA group 5 (Rainey et al., 1994). This group includes Bacillus stearothermophilus and other thermophilic Bacillus spp. Further analysis indicated that the levels of similarity ranged from 90 and $91 \%$ from B. stearothermophilus, B. thermocatenulatus, stearothermophilus, $B$. thermocatenulatus, $B$. thermoleovorans, $B$. denitrificans, B. flavothermus and $B$. thermoglucosidasius to $94 \%$ for $B$. caldoxylolyticus and Bacillus sp Strain AK1 (Fig.1).

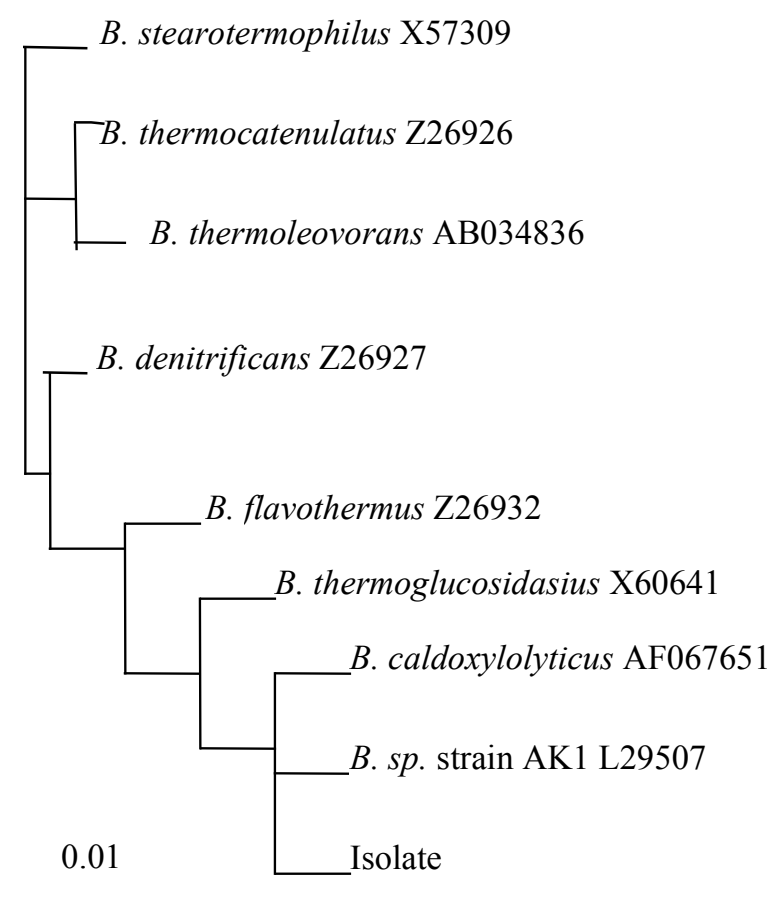

Figure 1 - Phylogenetic dendrogram based on 16SrDNA sequence data indicating the position of isolate among representatives of the genus Bacillus. All the sequences used in the analysis were obtained from the Ribosomal Database Project and Genbank. Scale bar indicates evolutionary distance.

The bacteria most closely related to strain Bacillus sp. AK1 (Maciver et al., 1998) for which 16S rRNA sequence data are available is $B$. thermoglucosidasius. This organism, described by Susuki et al., 1983, was isolated from soil and it was a obligate thermophile with an optimum temperature at $61-63^{\circ} \mathrm{C}$. Therefore, on the basis of phylogenetic studies we concluded that the isolate was closely related to the members of the Bacillus rRNA group 5 and was identified as Bacillus sp.
Enzymatic production: The growth pattern of Bacillus sp, xylanase activity and $\mathrm{pH}$ change were observed for five days in the liquid medium containing $0.5 \%$ xylan as a carbon source in 250 $\mathrm{mL}$ Erlenmeyer flask (Fig.2). The $\mathrm{pH}$ of the culture medium increased from 6.7 at the beginning to 7.5 in $36 \mathrm{~h}$ and then dropped to 6.8 at the and of fermentation. The organism grew logarithmically up to $36 \mathrm{~h}$ and there was no obvious correlation between growth and extracellular xylanase activity. The formation of xylanase started from $18 \mathrm{~h}$ and reached a maximum at $72 \mathrm{~h}$. Low amounts of extracellular xylanases were detected during the logarithmic growth phase of the Bacillus SSP-34 (Subramaniyan, Prema, Ramaktisna, 1997) and Bacillus sp (Nakamura et al., 1993).The increase in xylanase activity during later stages of growth might be due to the release of small amounts of xylanases from the aged cells entering into autolysis (Espinar et al., 1992) and also due to the scarcity of insoluble xylan particles in the medium which if present in the culture broth might bind the xylanases (Subramaniyan, Prema, Ramaktisna, 1997).

Effect of pH on activity and stability of xylanase: $\mathrm{A} \mathrm{pH}$ range between 5.5 and 8.5 was used to study the effect of $\mathrm{pH}$ on xylanase activity (Fig.3). Optimum $\mathrm{pH}$ was found to be between 6.5 and 7.0. The enzyme activity at $\mathrm{pH} 6,7$ and 8.5 were 87,97 and $64 \%$ of that at $\mathrm{pH} 6.5$ respectively. After incubation of crude enzyme solution for 24 hours at $\mathrm{pH} 5.5-8.0$ there was a decrease of about $12 \%$ of its original activity and at $\mathrm{pH} 8.5$ the decrease was of $32 \%$.

Effect of temperature on activity and stability of xylanase: The supernatant xylanolytic activities were assayed at different temperatures ranging from $30^{\circ} \mathrm{C}-100^{\circ} \mathrm{C}$ at a constant $\mathrm{pH}$ of 6.5 and a substrate concentration of $0.5 \%$ (Fig.4). Xylanase from the isolate exhibited a temperature profile with a sharp peak of maximal activity at $90^{\circ} \mathrm{C}$ and showing activity between $40-100^{\circ} \mathrm{C}$. The residual activities of crude xylanase incubated at different temperatures for a period of 2 hours were estimated at optimum temperature The enzyme was stable for 2 hours at temperatures ranging from $30-50^{\circ} \mathrm{C}$ while at $60^{\circ} \mathrm{C}, 70^{\circ} \mathrm{C}$ and $100^{\circ} \mathrm{C}$, $10 \%, 11 \%$ and $29 \%$ of the original activities were lost respectively. 


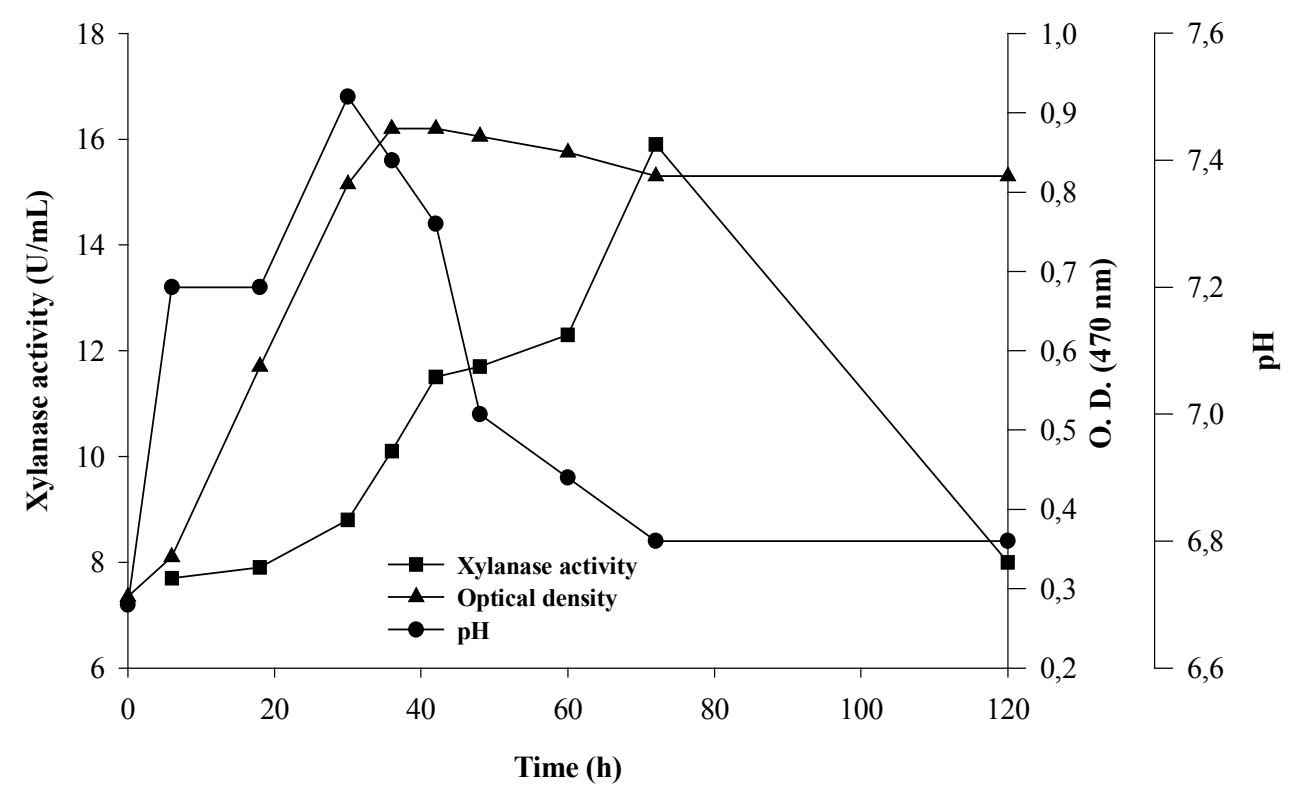

Figure 2 - Time course of xylanase production by Bacillus sp at $50^{\circ} \mathrm{C}$ on $0.5 \%$ beechwood xylan in shake flasks.

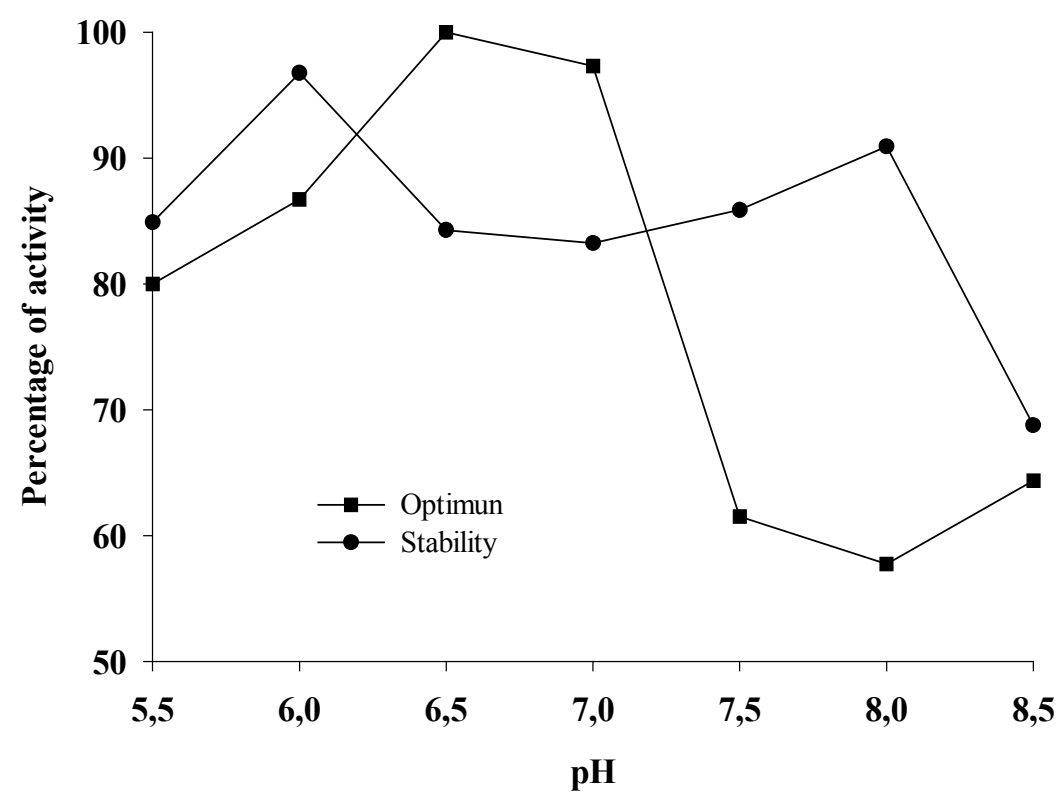

Figure 3 - Optimum pH and stability pH of Bacillus sp crude xylanase. 


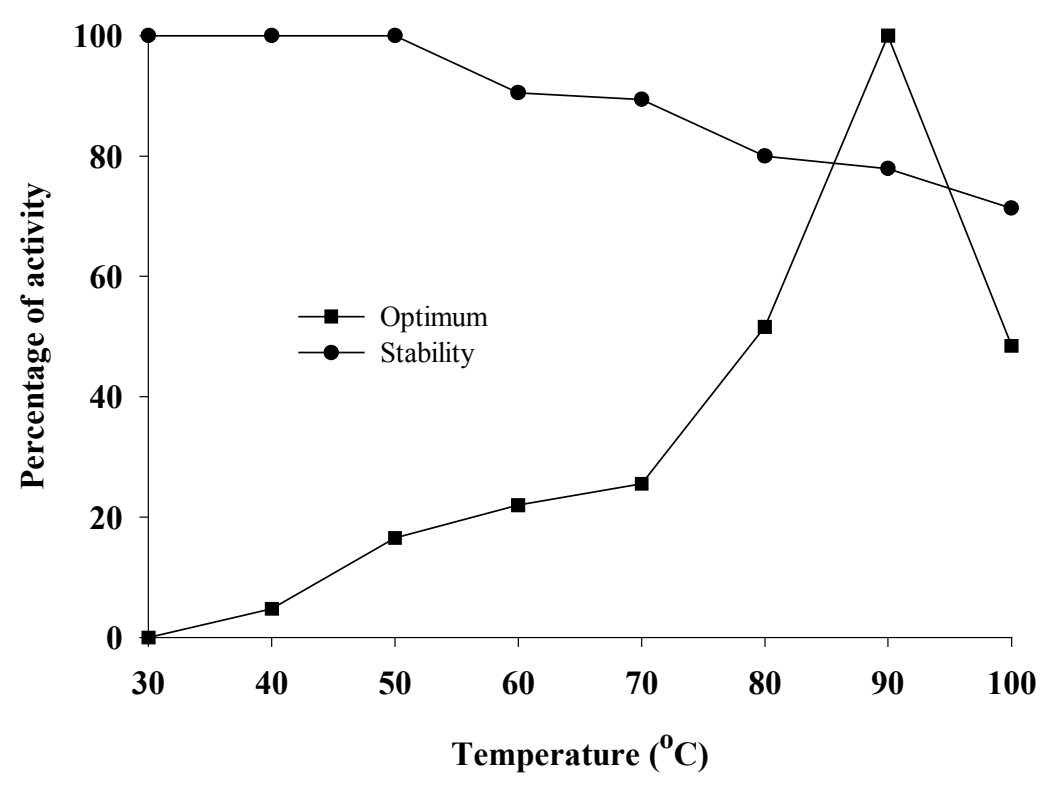

Figure 4 - Optimum temperature and stability temperature of Bacillus sp crude xylanase.

The temperature and $\mathrm{pH}$ stable xylanase from Bacillus sp 3M has been reported by Marques et al., (1998). The enzyme showed optimum activity at $60^{\circ} \mathrm{C}$ and retained $100 \%$ of activity for at least $3 \mathrm{~d}$ at $55^{\circ} \mathrm{C}$. At $80^{\circ} \mathrm{C}$, it retains $47 \%$ of its maximal activity.

Since thermal stability of xylanase is a very important propertie due to its potential applications in several industrial processes the strain isolated by us could be a good candidate for biotechnological applications.

\section{ACKNOWLEDGMENTS}

The authors are highly thankful to the Fundação de Amparo à Pesquisa do Estado do Rio de Janeiro for financial support and the Fundação André Tosello for performing the 16S rRNA sequence analysis.

\section{RESUMO}

Uma bactéria xilanolítica, termofílica e aeróbica foi isolada de amostras de solo local. Os resultados da comparação de seqüências de $16 \mathrm{~S}$ rRNA indicaram que $\mathrm{o}$ isolado foi proximamente relacionado com o Bacillus caldoxylolyticus and Bacillus sp AK1 e estes três organismos exibiram níveis de homologia de 94\% nas seqüências de DNA ribossomal. Estudos sobre a caracterização de xilanase de culturas líquidas cultivadas em xilana (beechwood), revelaram que a enzima permaneceu $100 \%$ ativa por 2 horas a temperaturas variando de $30^{\circ} \mathrm{C}$ a $50^{\circ} \mathrm{C}$, enquanto a $60^{\circ} \mathrm{C}, 70^{\circ} \mathrm{C}$ e $100^{\circ} \mathrm{C}, 10 \%, 11 \%$ e $29 \%$ de sua atividade original foi perdida. $\mathrm{O} \mathrm{pH}$ ótimo da enzima foi encontrado estar entre 6,5 e 7,0. Após a incubação da solução enzimática bruta por 24 horas a $25^{\circ} \mathrm{C}$ e a valores de $\mathrm{pH}$ variando de 5,5 a 8,0 , foi observado um decréscimo em torno de $12 \%$ de sua atividade original.

\section{REFERENCES}

Becker, P.; Abu-Reesh, I. and Markossian, S. (1997), Determination of the kinetic parameters during continuous cultivation of the lipase-producing thermophile Bacillus sp. IHI-91 on olive oil. App. Microbiol. Biotechnol., 48, 184-190. 
Beg, Q. K.; Bhushan, B.; Kapoor, M. and Hoondal, G. S. (2000), Production and characterization of thermostable xylanase and pectinase from Streptomyces sp. QG-11-3. J. Ind. Microbiol. \& Biotechnol., 24, 396-402.

Blanco, A.; Diaz, P.; Zueco, J.; Parascandola, P. and Pastor, F. I. J. A (1999), A multidomain xylanase from a Bacillus sp. with a region homologous to thermostabilizing domains of thermophilic enzymes. Microbiol., 145, 2163-2170.

Dimitrov, P. L.; Kambourova, M. S.; Mandeva, R. D. and Emanuilova, E. I. (1997), Isolation and characterization of xylan-degrading alkali-tolerant thermophiles. FEMS Microbiol. Letters., 157, 27-30.

Espinar, M. T. F.; Ramon, D.; Pinaga, F. and Walles, S. (1992), Xylanase production by Aspergillus nidulans. FEMS Microbiol. Letts, 91, 91-96.

Gessesse, A. and Gashe, B. A. (1997), Production of alkaline xylanases by an alkaliphilic Bacillus sp. isolated from na alkaline soda lake. J. Apll. Microbiol., 83, 402-406.

Gilbert, M.; Breu, C.; Aguchi, M. and Saddler, J. N. (1992), Purification and characterization of a xylanase from the thermophilic Ascomycete Thielavia terrestris 2558. Applied Biochemistry and Biotechnology, 3,4 247-259.

Godfrey,T. and West, S. (1996), Industrial Enzymology. 2. ed. New York: Stockton Press. 609 pp.

Jukes, T. H. and Cantor, R. R. (1969), Evolution of protein molecules. In: Munro, H. N. (ed.), Mammaalian protein metabolism. Academic Press, New York. pp. 221-132.

Larsen, N. A.; Olsen, G. J.; Maidak, B. L.; McCaughey, M. J.; Overbeek, R.; Marsh, T. J. and Woese, C. R. (1993), The Ribosomal Database Project. Nucleics Acids Res., 21, 3021-3023.

Lee, D. W.; Koh, Y. S.; Kim, K. J.; Kim. B. C.; Choi, H. J.; Kim, D. S.; Suhartono, M. T. and Pyun, Y. R. (1999), Isolation and characterization of a thermophilic lipase from Bacillus thermoleovorans ID-1. FEMS Microbiol. Lett., 179, 393-400.

Maciver ,B.; McHale, R. H.; Saul, D. J. and Bergquist, P. L. (1994), Cloning and sequencing of a serine proteinase gene from a thermophilic Bacillus species and its expression in Escherichia coli. Appl. Environ. Microbiol., 60, 3981-3988.

Marques, S.; Alves, L.; Ribeiro, S.; Gírio, F. M. and Amaral-Collaço, M. T. (1998), Chracterization of a thermotolerant and alkalotolerant xylanase from a Bacillus sp. Appl. Biochem. Biotechnol., 73159-172.

Mechaly, A.; Belakhov, V.; Shoham, Y. and Baasov, T. (1997), An efficient chemical-enzymatic synthesis of 4-nitrophenyl $\beta$-xylobiosede: a chromogenic substrate for xylanases. Carbohydrate Research, 304, 111-115.

Miller, G. L. (1959), Use of dinitrosalicylic acid reagent for determination of reducing sugars. Anal. Chem., 3, 426-428.
Nakamura, S.; Wakabayashi, K.; Nakai, R. and Horikoshi, K. (1993b), Production of alkaline xylanase by a newly isolated alkaliphilic Bacillus sp. strain 41M-1. World J. Microbiol. Biotechnol., 3, 221-224.

Pham, P. L.; Taillander, P.; Delmas, M. and Strehaiano, P. (1998), Optimization of a culture medium for xylanase production by Bacillus sp. using statiscal experimental designs. World J. Microbiol. \& Biotecnol., 14, 185-190.

Rainey, F. A.; Fritze, D. and Stackebrandt, E. (1994), The phylogenetic diversity of thermophilic members of the genus Bacillus as revealed by $16 \mathrm{~S}$ rDNA analysis. FEMS Microbiol. Lett., 115, 205-212.

Saitou, N. and Nei, M. (1987), The neighbor-joinig method: a new method for recontructing phylogenetic trees. Mol. Biol. Evol., 4, 406-425.

Shieh, W. Y. and Jean, W. D. (1998), Alterococcus agarolyticus, gen.nov., sp.nov., a halophilic bacterium capable of agar degradation. Can. J. Microbiol., 44, 637-645.

Sonnleitner, B. and Fiechter, A. (1983) Advantages of using thermophiles in biotechnological processes: expectations and reality. Trends in Biotechnology, 1, 74-80.

Subramaniyan, S.; Prema, P. and Ramakrisna, S. V. (1997), Isolation and screening for alkaline thermostable xylanases. J. Basic. Microbiol., 37, 431-437.

Sunna, A., Antranikian, G. (1997), Xylanolytic enzymes from fungi and bacteria. Crit. Rev. Biotechnol., 17, 39-67.

Sunna, A.; Prowe, S. G.; Stoffregen, T. and Antranikian, G. (1997), Characterization of the xylanases from the new isolated thermophilic xylandegrading Bacillus thermoleovorans strain K-3d and Bacillus flavothermus strain LB3A. FEMS Microbiol. Lett., 148, 209-216.

Susuki, Y.; Kishigam, T.; Inoue, K.; Mizoguchi, Y.; Eto, N.; Takagi, M. and Abe, S. (1983), Bacillus thermoglucosidasius sp. nov., a new species of obligately thermophilic bacilli. System. Appl. Microbiol., 4, 487-495.

Touzel, J. P.; O’Donohue, M.; Debeire, P.; Samain, E. and Breton, C. (2000), Thermobacillus xylanilyticus gen. Nov., sp. nov., a new aerobic thermophilic xylan-degrading bacterium isolated from farm soil. Int. J. Syst. Evol. Microbiol., 50, 315-320.

Van der Broeck, H. C.; De Graaff, L. L.; Hille, J. D. R.; Van Ooyen, A. J. J. and Harder, A. (1990), Cloning and expression of fungal xylanase genes and use of the xylanase in bead making and in preparation of feed and paper products. Eur. Pat. Appl., 90, 202-220.

Wong, K. K. Y.; Tan, L. U. and Saddler, J. N. (1988), Multiplicity of $\beta-1,4$-xylanases in microorganisms: functions and applications. Microbio. Ver., 52, 305-317.

Received: November 22, 2000; Revised: September 21, 2001; Accepted: December 18, 2001. 